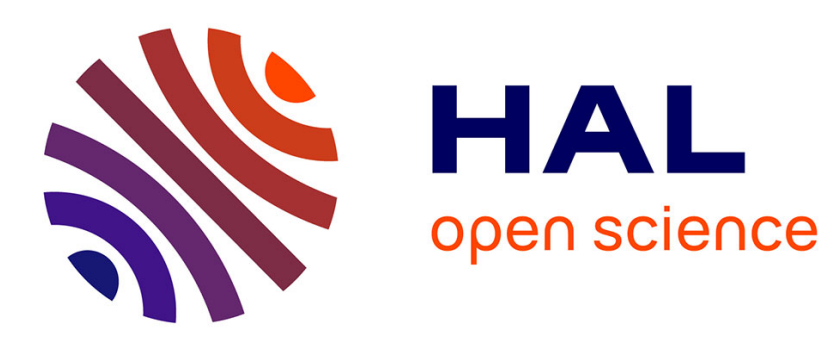

\title{
WHAT FACTORS DETERMINE THE OUTSOURCING INTENSITY? A Dynamic Panel Data Approach for manufacturing industries
}

Carmen Diaz-Mora

\section{- To cite this version: \\ Carmen Diaz-Mora. WHAT FACTORS DETERMINE THE OUTSOURCING INTENSITY? A Dy- namic Panel Data Approach for manufacturing industries. Applied Economics, 2008, 40 (19), pp.2509- 2521. 10.1080/00036840600970179 . hal-00582001}

\section{HAL Id: hal-00582001 https://hal.science/hal-00582001}

Submitted on 1 Apr 2011

HAL is a multi-disciplinary open access archive for the deposit and dissemination of scientific research documents, whether they are published or not. The documents may come from teaching and research institutions in France or abroad, or from public or private research centers.
L'archive ouverte pluridisciplinaire HAL, est destinée au dépôt et à la diffusion de documents scientifiques de niveau recherche, publiés ou non, émanant des établissements d'enseignement et de recherche français ou étrangers, des laboratoires publics ou privés. 


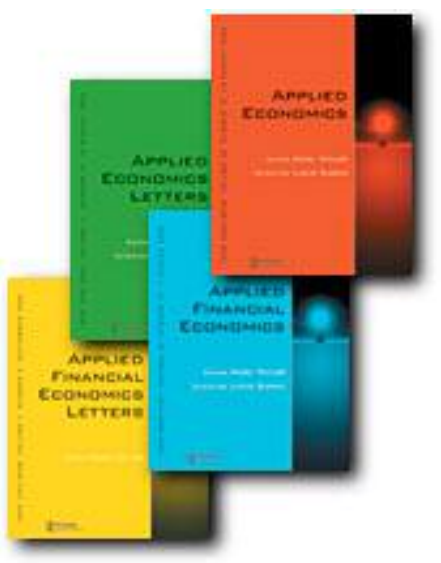

WHAT FACTORS DETERMINE THE OUTSOURCING INTENSITY? A Dynamic Panel Data Approach for manufacturing industries

\begin{tabular}{|r|l|}
\hline Journal: & Applied Economics \\
\hline Manuscript ID: & APE-05-0542.R1 \\
\hline Journal Selection: & Applied Economics \\
\hline JEL Code: & $\begin{array}{l}\text { L22 - Firm Organization, Market Structure: Markets vs. Hierarchies; } \\
\text { Vertical Integration < L2 - Firm Objectives, Organization, and } \\
\text { Behavior < L - Industrial Organization, L60 - General < L6 - } \\
\text { Industry Studies: Manufacturing < L - Industrial Organization, L23 - } \\
\text { Organization of Production < L2 - Firm Objectives, Organization, } \\
\text { and Behavior < L - Industrial Organization }\end{array}$ \\
\hline Keywords: & $\begin{array}{l}\text { Outsourcing, Manufacturing industry, Subcontracting, Unit labor } \\
\text { costs }\end{array}$ \\
\hline
\end{tabular}

powered by ScholarOne

Manuscript Central ${ }^{\text {H }}$ 


\title{
WHAT FACTORS DETERMINE THE OUTSOURCING INTENSITY?*
}

\begin{abstract}
:
The present paper investigates the determinants of outsourcing production using a panel of 93 Spanish manufacturing industries for the period 1993-2002. Outsourcing is measured as production tasks which are contracting out to external suppliers, a more direct and suitable indicator. After controlling for unobserved heterogeneity and simultaneity, our results show a high persistence of the outsourcing intensity. Moreover, outsourcing of production is positively related to unit labour costs, skills requirements, national ownership and orientation to international markets. We also find evidence for a negative link between the outsourcing intensity and the share of small firms.
\end{abstract}

JEL classification: L23, L60.

Key words: Outsourcing, Manufacturing Industries, Explanatory Factors, Unit Labour Costs. 


\section{INTRODUCTION}

According to international empirical evidence, a new and complex production organization strategy is currently being developed. This strategy, called fragmentation of production, favours the splitting up of production processes into more specialized and discernible phases in order to obtain the most efficient producer and location for each product or component. It is devised mainly by developed-countries' enterprises, which face a very competitive market where, on the one hand, products coming from developing countries are highly competitive due to lower labour and production costs and, on the other hand, customers demand highly differentiated products. The main aim of adopting it is to take advantage of specialization and scale economies in components or other production tasks by specialized suppliers as well as to gain flexibility to respond to demand changes quickly. In this way, firms specialize in those activities or phases where they have a competitive edge seeking to improve production efficiency, and consequently, their competitiveness.

Two dimensions of fragmentation can be distinguished (Curzon Price, 2001; Kimura and Ando, 2005): an ownership dimension and a geographical dimension (Figure 1). The first one refers to the controllability of a firm over fragmented production and the second one does to the geographical location of that segmented production. One of the most important features of fragmentation of production is that more and more often goes beyond the boundaries of the firm. When the segmented production is carried out by other independent firms, the term outsourcing ${ }^{\mathrm{ii}}$ is used. Outsourcing comprises dimensions 2 and 3 of fragmentation of production in Figure 1. It is important to note that even though there is no direct shareholder control over the segmented phases, it does not mean that there is not any control over them at all. Transactions cannot be considered completely independent market transactions for two reasons: firstly, because the relationship between companies has a long-term nature, and secondly, because of the great quantity of information, such as detailed instructions and specifications, which the external provider receives. As Curzon Price (2001) points out, outsourcing lies somewhere in between 
total ownership and complete arm's length transactions. Moreover, the externalized production can be outsourced to suppliers located abroad (international or foreign or cross-border outsourcing) or to domestic providers (national or domestic outsourcing).

Outsourcing of production is thus understood as a process of vertical disintegration of the value chain where some phases or even the whole production process are now contracting out to external enterprises instead of performing inside the firm. This is the aspect of fragmentation we want to study. Our data can not allow to distinguish between national or foreign suppliers, so we focus on total outsourcing which comprises domestic and cross-border outsourcing. Understanding what factors determine the intensity of total outsourcing production using panel data is the object of the present paper.

In spite of the increasingly use of outsourcing of production activities according to business press ${ }^{\mathrm{iii}}$ and academic literature, empirical research about its determinants remains very limited: Kimura (2001) and Tomiura (2005) for Japanese manufacturing industry, Görg and Hanley (2004) for Irish electronics industry, Girma and Görg (2004) for some UK manufacturing industries and Holl (2004) for Spanish manufacturing industry. Of these, only the last three are panel data instead of cross-section analysis and exclusively Görg and Hanley (2004) and Girma and Görg (2004) try to infer the factors that may affect the level of outsourcing, whereas Holl (2004) focuses on the determinants of the probability that a firm does take the decision of outsourcing using a probit model.

Hence, as far as the author knows, our study is the first on the determinants of outsourcing intensity using panel data for the Spanish manufacturing industry. The estimation includes the GMM approach proposed by Blundell and Bond (1998) especially suitable to deal with models for moderately persistent series from short panels. Furthermore, this paper contributes to the empirical literature by employing a direct and more adequate indicator for outsourcing of internal production. This type of outsourcing is often measured by the ratio of material intermediate inputs to output. But this is a broad measure because it includes raw 
materials purchases and arms-length purchases of standardized components in the market. A specific characteristic of outsourcing is that the relationship between the firm which contracts out production and external provider is long-term and it usually implies sharing information about the product. That is, purchases of intermediate inputs through a usual marketing channel have not to be regarded as outsourcing. As Grossman and Helpman (2005) notes "outsourcing means more than just the purchases of raw materials and standardized intermediate goods". At the same time, the ratio of material intermediate inputs to output is a narrow indicator because it does not capture the outsourcing of the final production stage, the assembly or specific production tasks.

For these reasons, we use an indicator that fulfils these required conditions. This is Production works done by other firms which refers to tasks which being a part of the own production process are carried out by other firms. It involves contracting out manufacturing of parts and components and also any stage of the production process such as product design or specific tasks (for instance, in the textile industry, tailoring or press ironing) or even the final assembly ${ }^{\text {iv }}$. That is, neither external services such as maintenance of fixed assets, accounting, consulting, cleaning, transportation, etc., nor purchases of raw materials and supplies such as office materials or fuel are included. Subcontracts are included within this concept ${ }^{\mathrm{v}}$.

The paper is structured as follows. In the next section, we briefly review previous literature on the determinants of outsourcing. In section III we describe the data set used for the empirical analysis and then we present some descriptive statistics as well as the econometric model. The results of the empirical estimation are showed in section IV. Lastly, in section V, some conclusions are made.

\section{DETERMINANTS OF OURTSOURCING OF INTERNAL PRODUCTION.}

Companies will opt for outsourcing when externalisation of certain value chain phases allows them to reduce costs and when de-internalizing has more advantages than in-house production. The technological revolution that has taken place in last decades has allowed for a significant drop in the costs associated with finding information, transport communication and 
business coordination, lowering the transaction costs and augmenting the possibilities for outsourcing.

According to transaction cost theory (Coase, 1937; Williamson, 1975), outsourcing would entail a variety of coordination costs associated with various aspects of inter-firm transactions. Search costs to find the right supplier, negotiation costs, costs to design the contract and the incomplete contracts problem, coordination costs, technology transfer risks, etc. have to be considered $^{\mathrm{vi}}$. At the same time, firms which outsource production search to obtain two types of advantages: first, an increase of flexibility for adapting to changes in demand and technological conditions and, second, a reduction in production costs ${ }^{\mathrm{vii}}$.

If firms outsource in order to reduce costs relative to in-house production and, therefore, to increase efficiency, we would expect that those firms and sectors where the labour costs are higher were more active in outsourcing strategy. To test the relevance of the labour cost-saving motive for outsourcing, Girma and Görg (2004) include the wage rates for skilled and unskilled workers. However, they do not obtain conclusive results. The sign of the coefficient changes depending on the manufacturing industry and on the estimation technique and frequently the variable is statistically insignificant. Görg and Hanley (2004) introduce the average wage per employee when they investigate outsourcing determinants. They also find that the effect of wages is statistically insignificant and not robust to different estimation techniques. Holl (2004) does obtain a positive and significant coefficient of the wages on the probability of subcontracting products, parts and components.

In our opinion, a variable more relevant than wage is unit labour cost, that is, the remuneration of labour to produce one unit of output. This indicator of cost pressures in the labour market is computed as the ratio of labour cost to output. It is measured as well as the ratio of labour cost per worker (or per hour worked) divided by labour productivity (output per worker or per hour worked). By this way, changes in unit labour cost are the result of two forces: changes in wage rate and changes in productivity. It has been assumed that high wage firms do 
more outsourcing because the cost cutting motive will be more important. But those high wages could respond to higher efficiency due to high skills, resulting in lower unit labour costs. That is, it would be the wage, once productivity differences are taken into account, one of the key drivers of outsourcing. Hence, we expect that high unit labour cost manufacturing industries tended to contract out more production works than the rest ${ }^{\mathrm{viii}}$. This result would confirm the initial hypothesis that fragmentation of internal production is an strategy carried out by developedcountry firms in order to improve their efficiency in a context of strong competitiveness coming from cheaper labour regions.

As Abraham and Taylor (1996) suggest, the cost savings derived from outsourcing can be obtained by two ways: first, exploiting the economies of scale in producing these specialized components or phases which are being contracted out (outsourcing for specialization) and, second, turning fixed costs in variable costs and gaining flexibility if there are frequents fluctuations in the product demand (outsourcing for capacity).

The specialization motive for outsourcing introduces firm size as a determinant of this strategy. There may be economies of scale in the production of specific inputs and, in this sense, size variable have to be considered to control for this scale economies effect. Since small and medium enterprises will have more difficulties to reap the minimum efficient scale, they will opt more intensively for outsourcing.

Nevertheless, we also argue that outsourcing is an strategy for gaining flexibility that allows large firms to reduce their rigidity. In a very strong competence environment, a high grade of product differentiation is increasingly required. Consumers demand more and more specific product characteristics and firms have to achieve flexibility to adapt to changes in consumer wishes. Contracting out the manufacturing of specific components or tasks is one of the alternatives to obtain it. That is, firms would tend to back to the basics focussing on those activities where they are more efficient and outsourcing the rest. In this sense, large firms have more incentives to carried out this process of vertically de-integration of production structures. 
Another reason to expect a positive relationship between size and outsourcing intensity is proposed by Tomiura (2005), who suggests that smaller firms could face to higher search costs, that is, due to stronger market power large firms might find contracting partners more easily.

The sign of firm size is, therefore, ambiguous. Whereas empirical works such as Holl (2004) have obtained positive coefficients, the sign is negative in Görg and Hanley (2004). This last study, however, excludes small firms because it uses a Survey that provides information only for firms with thirty or more employees.

The size or thickness of the market is also related with the outsourcing intensity. The larger the market, the more chance of finding a good external supplier and, therefore, more likely to engage in outsourcing. Grossman and Helpman (2002) and McLaren (2000) consider the effects of market thickness on the outsourcing of intermediate inputs in their transaction cost models where the trade off between vertical integration and outsourcing is investigated. Since international trade increases the ease for a firm to math with an specialized input provider, one expects that higher international trade lead to a rise in outsourcing through an increase in market thickness. Empirical works such as Görg and Hanley (2004) introduce export propensity pointing that export propensity may have a positive effect on outsourcing. It could be argued that the more a company exports, the more the possibilities there are in finding specialized foreign suppliers.

Previous works usually control for ownership nationality. According to Görg and Hanley (2004) and Girma and Görg (2004), since foreign firms are part of an international network competing in a global market, the potential to contract out to more efficient producers abroad increases. Hence, it could be assumed that they do more outsourcing than domestic firms. However, if foreign affiliates are located in a country just for doing production tasks for the parent company, the possibility from these manufacturing plants for using subcontractors could decrease. The sign of national ownership variable is, as well as firm size, ambiguous and will be 
an empirical matter. Previous works have obtained positive signs (Girma and Görg, 2004) but also negative signs (Holl, 2004; Görg and Hanley, 2004).

Finally, it seems reasonable that the decision about the outsourcing intensity in period $t$ is related to the level of outsourcing in previous period t-1. The lagged dependent variable is taken into account to consider the persistence in the outsourcing decision (Girma and Görg, 2004). Moreover, Swenson (2004) shows that outsourcing exhibits hysteresis caused by sunk entry costs using data of the U.S. offshore assembly program. The existence of important transaction costs would explain the persistence in the outsourcing intensity. They are a key difficulty in the decision of outsourcing internal production according to the theoretical model by Grossman and Helpman (2002). These costs will be higher in the first moments, when the outsourcing strategy is becoming to be used. There would be sunk entry costs associated with outsourcing strategy (such as search costs in finding a suitable provider). In following years, transaction costs probably will be decreasing and they will be compensated by the advantages of farming out parts of the production process. These explanatory variables and the expected signs in previous outsourcing literature are summarized in table 2.

\section{DATA AND METHODOLOGY DESCRIPTION.}

In order to investigate the determinants of outsourcing of internal production we use industry level data for manufacturing in Spain. The data are derived from the Industrial Companies Survey (Encuesta Industrial de Empresas) published by the Spanish National Statistics Institute. The Survey, which is undertaken annually since 1993, provides information on employed persons, wages, hours worked, sales, intermediate inputs, external services and some more variables for 93 manufacturing industries. The sectors correspond mostly to the 3digit level of NACE Rev.1 (Table 1). The Survey basic unit is industrial company with one or more remunerated employed persons. Approximately 43,000 firms compose the sample in 2002.

The inclusion of the variable Production works done by other firms, as defined in the introduction section, makes the Survey particularly interesting for our analysis of outsourcing of 
internal production. We measure outsourcing of internal production as the ratio of these production tasks carried out by other firms to gross output. If the ratio goes up, we interpret that manufacturing firms are replacing in-house production for external contract production.

Figure 2 plots the extent of outsourcing for Spanish manufacturing industries in 2002. We observe the heterogeneity in the outsourcing intensity among sectors. Outsourcing level is higher for Textile Industries, Wearing Apparel, Footwear, Publishing and Printing, Fabricated Metal Products and Shipbuilding and Aerospace Industry. All of them show fragmentation levels well above $10 \%$ of gross production, and $20 \%$ for the last two sectors. According to this indicator, for the average Spanish manufacturing industry around 5\% of output are production works contracted out to outside producers. Moreover, our data show that fragmentation of production has increased steadily in many sectors (average rise of 40\% from 1993 to 2002) ${ }^{\text {ix }}$. Therefore, we find evidence of the growing disintegration of the production process and rising of outsourcing production activities in Spain.

In order to obtain more information about the characteristics of those sectors where outsourcing is more intensive, we use a classification which cluster industries by their typical input combinations: labour-intensive, technological-driven, capital intensive, marketing-driven and mainstream manufacturing industries (Peneder, 1999). Outsourcing is common to all groups of industries. Nevertheless, it is more relevant for labour-intensive industries where most of these sectors shows outsourcing levels above average, many of them even above $10 \%$ of the gross production (which can be interpreted as a high level of outsourcing). So, we argue that industries producing goods intensive in labour relative to capital and technology seem to give stronger support to fragmentation based on contract out physical production to specialized producers than the rest of industries (Figure 3).

To analyse the determinants of outsourcing of internal production we consider the following regression equation which relates outsourcing intensity to a broad range of industry's characteristics: 


$$
\begin{aligned}
& \text { OUTS }_{\text {it }}=\beta_{0}+\beta_{1} \text { OUTS }_{\mathrm{i}, \mathrm{t}-1}+\beta_{2} \mathrm{ULC}_{\mathrm{it}}+\beta_{3} \% \text { Small-Firms }_{\text {it }}+\beta_{4} \text { National-own }_{\text {it }}+ \\
& \beta_{5} \text { Export-prop }_{\text {it }}+\beta_{7} \text { DSKILLS }_{\mathrm{it}}+\beta_{8} \mathrm{D}_{\mathrm{t}}+\mathrm{u}_{\mathrm{it}}
\end{aligned}
$$

Where i represent the 92 manufacturing $\operatorname{sectors}^{\mathrm{x}}$, $\mathrm{t}$ is the time period 1993-2002, OUTS is the outsourcing level measured as production works carried out by other firms per unit of output, UCL are the unit labour costs measured as defined above and \%Small-Firms variable is the percentage of small firms (less than 20 employees) in a sector. We include a variable of ownership nationality (National-own.) which reflects the percentage of domestic firms (those with one hundred percent of national capital). Export-prop. is the export propensity ratio measured as exports to output. If firms use outsourcing as a cost-cutting strategy, we would expect that high skill sectors gave stronger support to fragmentation based on contracting out production phases to specialized producers than the rest of the industries, mainly those production tasks more intensive in low skilled labour ${ }^{\mathrm{xi}}$. For this reason, the model also includes a dummy variable to control for high skill requirements (DSKILLS), which takes on value 1 for sectors with high skill requirements and 0 for the rest using the Peneder (1999) classification. This classification is based on the OECD's occupational data, which distinguish between white and blue-collar workers, on the one hand, and between high and low skilled labour on the other. At last, 10 time dummies are introduced to control for period-specific effects.

The equation (1) represents a standard dynamic model, where lagged dependent variable is included among the regressors. Furthermore, we will treat the unit labour cost variable as endogenous, since it is conceivable that changes in outsourcing level lead to changes in future unit labour cost. For similar reasons, we consider the share of small firms and the export propensity ratio as not strictly exogenous and we also include these variables lagged.

We calculate the outsourcing intensity, the unit labour costs and the percentage of small firms from data of the Industrial Companies Survey. Data for the ownership are drawn from the firm level panel survey, the Survey of Firm Strategies (Encuesta sobre Estrategias 
Empresariales, ESEE) of the Spanish Ministry of Science and Technology which offers data for 20 manufacturing industries.

All variables are expressed in logarithms. We use a one-way error component model for the disturbance term, $u_{i t}=\alpha_{i}+v_{i t}$, where $\alpha_{i}$ denotes the unobservable individual specific effects that are independent and identically distributed (iid) over the sectors with variance $\sigma_{\alpha}{ }^{2}$ and $v_{\text {it }}$ denotes the remainder disturbance that are iid over the whole sample with variance $\sigma_{v}{ }^{2}$. The time invariant variables are often difficult to measure or hard to obtain. For example, a sector-specific production technology may allow the dispersion of phases of production process better in that sector than in another sector. This production technology varies across sectors but it is not expected to change very much in a short time period.

Taking into account these three aspects (potential industry unobserved heterogeneity, dynamic nature of the model and endogeneity of some explanatory variables), the appropriate estimator is the Generalized Method of Moments (GMM) developed by Arellano and Bond (1991). They suggest first differencing the model to get rid of the industry specific effects and then using valid instruments (lagged values of the instrumented variables) to deal with the problem that by construction the new error term is correlated with the lagged dependent variable. The use of instruments is also required to control for the potential endogeneity of other explanatory variables. We use at least three lagged values of unit labour cost as instruments for the equations in first differences to control for the potential influence of current outsourcing level on current unit labour cost. The same lagged values are chosen for the rest of the endogenous variables. Since national ownership is assumed to be strictly exogenous, it is instrumented with itself.

A draw back of the difference GMM estimator of Arellano and Bond (1991) is that when first differences are taken, time invariant variables are wiped out. So, the estimator does not use cross sectional information reflected in the differences between industries. Another disadvantage is that lagged levels are often poor instruments for the equation in differences, especially in the 
case of panel with a small number of time periods with highly persistent data. It can cause large finite-sample biased and poor precision in the estimators. To reduce this problem associated with the difference GMM estimator, we use a new estimator, the system GMM, developed by Arellano and Bover (1995) and Blundell and Bond (1998). This estimator is based on an augmented system that includes the regression in differences in addition to the regression in levels with lagged differences as instruments. The second part of the system requires the additional assumption of no correlation between the variables in differences and the unobserved industry effects, although there may be correlation between the levels of the explanatory variables and the fixed effects.

Some summary statistics for the variables used are provided in Table 3. We observe that, in manufacturing industry labour cost are about 20 percent of the output value and about 30 percent of the output is sold to foreign markets. In addition to, small firms as well as firms without any foreign participation are clearly predominant in Spanish industry (around 80 percent of total industries). Table 4 presents the simple correlations between pairs of variables. Since the correlations between the independent variables are small (except between the shares of small firms and national firms), we interpret there are not multicollinearity problem in the regressions. In addition, we see that outsourcing is positively correlated with most of the independent variables, mainly with levels of the unit labour costs, the proportion of domestic firms and the high skill requirements. Nevertheless, the outsourcing intensity is determined jointly with these variables and other factors which have to be controlled. For these reasons, an econometric analysis is applied.

\section{ECONOMETRIC RESULTS.}

The results of the econometric analysis are reported in Table 5. The first column presents the outcomes from the estimation of equation (1) using GMM system procedure. The positive and significant coefficient of lagged dependent variable indicates a high degree of persistence in outsourcing strategy. Moreover, in line with our prior expectations, higher unit labour costs are 
related to higher level of outsourcing. We can interpret that sectors tend to use fragmentation of production as a defensive strategy trying to improve their competitiveness. The positive and significant coefficient of unit labour cost is an important result because it provides empirical evidence of the cost-cutting motive for outsourcing. Additionally, according to the positive link between the share of domestic firms and the outsourcing level, as the percentage of national firms increases, so do outsourcing activities. This result would contradict that foreign firms were more prone to contract out internal production. In our opinion, this is because the last have been located in Spain as production affiliates carrying out parts of the production process for the parent firm. Moreover, the dummy variable high skill requirements exhibits a positive and significant sign showing that industries intensive in high skilled-labour tend to farm out internal production more intensively. Lastly, two variables, the percentage of small firms and the export propensity, are statistically insignificant. Most of the time dummy variables are highly significant although, in order to spare space, the coefficients are omitted from the results table.

Consistency of the GMM estimators depends on the validity of the instruments which is examined by four specifications tests. The first is the Sargan test of overidentifying restriction. The Sargan test does not reject the validity of the instruments employed in the estimation process. Since system GMM used additional moment conditions over the difference GMM, a Sargan Difference test can be employed to examine the validity of these additional instruments obtained from the equation in levels. The Sargan difference test does not rejected the validity of them $\left(\chi^{2}[8]=5.53\right)$. The validity of the instruments also requires the lack of second order serial correlation in the dynamic formulation whereas, by construction, first-order correlation is expected even with uncorrelated original error term. Two additional tests are included to examine the absence serial correlation in first differenced residuals. The null hypothesis of no second order correlation cannot be rejected and we can conclude that original error is not serially correlated. 
We test the robustness of the regressions by removing those variables which do not have a significant impact on the dependent variable. The column 2 of Table 5 presents the results from the estimation of equation (1) excluding the share of small firms whereas we have removed the export propensity in the column 3. According to the System GMM estimations, the positive coefficients for previous outsourcing intensity, unit labour cost, national ownership and skill requirements remain robust. Moreover, the negative coefficient of the share of small firms turns out significant when export propensity is not included. According to this result, those sectors where the share of small firms is lower outsource more internal production than the rest, pointing the existence of less difficulties in searching specialized outside producers for large firms.

Taking into account the interaction between the share of small firms and the export propensity variable, we use a variable for international market penetration measured as the percentage of firms in each sector whose main market is foreign ${ }^{\text {xii }}$ (column 4 and of table 5). In this case, both variables (size variable and foreign market penetration) are significant. The positive and significant coefficient points out that outsourcing intensity grows when the proportion of firms which produce mostly to foreign markets does. By this way, firms orientated mainly to international markets would use more intensively outsourcing strategy. A greater pressure to improve their efficiency and competitiveness or a greater probability to find specialized suppliers could explain this outcome.

Finally, table 5 contains a last column where the model for a sub-sample of more homogeneous 3-digits sector is estimated ${ }^{\text {xiii }}$. In particular, we have considered exclusively labour intensive sectors according to Peneder taxonomy. Previous outsourcing level and unit labour costs remains positive and highly significant pointing out the robustness of the empirical estimates for these variables. For labour intensive sector, neither firm size nor national ownership seem to have an significant impact on outsourcing intensity. On the contrary, export propensity shows a positive and significant coefficient. 


\section{CONCLUSIONS.}

In this paper we have investigated the determinants of outsourcing of internal production using industry level data for Spanish economy. Our study covers 93 manufacturing sectors and the period 1993-2002. We observe that manufacturing industries are fragmenting the value chain and they are opting increasingly for contracting out production works to specialized providers.

We test a model where the outsourcing intensity at industry-level depends on lagged level of outsourcing, unit labour cost, share of domestic firms, proportion of small firms, export propensity and skill requirements. We employ the system-GMM estimator proposed by Blundell and Bond (1998) that provides better instruments when right-hand variables are persistent over time.

We find that current level of outsourcing is highly related to previous outsourcing intensity, that is, outsourcing exhibits hysteresis. The market transaction costs associated to contracting out production are probably higher when firms make the decision of outsourcing (some of them are even sunk costs). In due course, some of these costs will be reduced and so the advantages of in-house production will be dropped. Therefore, if firms are achieving their objectives of gaining flexibility and decreasing costs, the outsourcing strategy will be used more and more intensively allowing firms to concentrate on their innermost core competence.

Furthermore, our results show that the unit labour costs affect positively the ratio of production works that are contracted out to external providers related to output. The pressure of low-cost competitors could be more intensive in manufacturing industries with higher unit labour costs and, therefore, they would be mostly encouraged to outsource production works to cheap and specialized contract manufacturers. We find significant evidence for the positive link between the outsourcing intensity and the share of domestic firms, the orientation to foreign markets as well as the high skill requirements. Finally, we observe a negative effect of the share of small firms on outsourcing intensity. 


\section{References}

Abraham, K. and Taylor, S. (1996): Firm's use of outside contractors: theory and evidence, Journal of Labour Economics, 14, 394-424.

Antras, P. (2003): Firms, Contracts and Trade Structure, Quarterly Journal of Economics, 118, $1375-1418$.

Antras, P. and Helpman, E. (2004): Global outsourcing, Journal of Political Economy, 112(3), 552-580.

Arellano, M. and S. Bond (1991): Some tests of specification for panel data: Monte Carlo evidence and an application to employment equations, Review of Economic Studies, 58 (2), 277-297.

Arellano, M. and O. Bover (1995): Another look at the instrument variable estimation of errorcomponents models, Journal of Econometrics, 68 (1), 29-52.

Blundell, R. and S. Bond (1998): Initial conditions and moment restrictions in dynamic panel data models, Journal of Econometrics, 87 (1), 115-143.

Buehler, S. and Haucap, J. (2006): Strategic outsourcing revisited, Journal of Economic Behaviour and Organization, forthcoming.

Coase, R. (1937): The Nature of the firm, Economica, New Series, 4, 386-405.

Curzon Price, V. (2001): Some causes and consequences, in Fragmentation: New production patterns in the world economy (Eds.) S.W. Arndt and H. Kierzkowski, Oxford University Press, Oxford.

Eckel, C. (2004): International trade, flexible manufacturing and outsourcing, CeGE Discussion Papers 45, University of Goettingen, Goettingen.

Girma, S. and Görg, H. (2004): Outsourcing, foreign ownership and productivity: evidence from UK establishment level data, Review of International Economics, 12, 817-832.

Görg, H. and Hanley, A. (2004): Does outsourcing increase profitability?, The Economic and Social Review, 35 (3), 367-387.

Görzig, B. and Stephan, A. (2002): Outsourcing and firm-level performance, Discussion Paper No. 309, DIW Berlin, Berlin.

Grossman, G.M. and Helpman, E. (2002): Integration versus outsourcing in industry equilibrium, Quarterly Journal of Economics, 117 (1), 85-120.

Grossman, G.M. and Helpman, E. (2005): Outsourcing in a global economy, The Review of Economic Studies, 72 (1), 135-160.

Holl, A. (2004): Production subcontracting and location: Panel data evidence from Spanish manufacturing firms, TRP Working Paper 146, University of Sheffield, Sheffield. 
Kimura, F. (2001): Fragmentation, internalization, and interfirm linkages: Evidence from the micro data of Japanese manufacturing firms, in Global Production and Trade in East Asia (Eds.) L.K. Cheng and H. Kierzkowski, Kluwer Academic Publishers, Boston.

Kimura, F. and Ando, M. (2005): Two-dimensional fragmentation in East Asia: conceptual framework and empirics, International Review of Economics and Finance, 14, 317-348.

McLaren, J. (2000): Globalization and Vertical Structure, American Economic Review, 90, 1239-1254.

Peneder, M. (1999): Intangible investment and human resources. The new taxonomy of manufacturing industry, Working Papers No. 114, WIFO, Vienna.

Piga, C. and Vivarelli, M. (2003): Sample selection in estimating the determinants of cooperate R\&D, Applied Economics Letters, 10, 243-246.

Piore, M.J. and Sabel, Ch.F. (1984): The Second Industrial Divide Possibilities for Prosperity, Basic Books, New York.

Shy, O. and Stenbacka, R. (2003): Strategic outsourcing, Journal of Economic Behaviour and Organization, 50, 203-224.

Swenson, D.L. (2004): Entry costs and outsourcing decisions: evidence from the U.S. overseas assembly provision, North American Journal of Economics and Finance, 15, 267-286.

Tomiura, E. (2005): Foreign outsourcing and firm-level characteristics: evidence from Japanese manufacturers, Journal of the Japanese and International Economics, 19, 255-271.

Williamson, O. (1975): Markets and hierarchies: Analysis and antitrust implications, Macmillan, New York. 


\section{Table 1: Sectoral disaggregation of Industrial Companies Survey 2002}

\begin{tabular}{|c|c|}
\hline Manufactures of food products, beverages and tobacco & Manufacture of fabricated metal products \\
\hline 151 Production, processing, preserving of meat, meat products & 2811 Manufacture of metal structures and parts of structures \\
\hline 152 Processing and preserving of fish and fish products & 2812 Manufacture of builders' carpentry and joinery of metal \\
\hline 153 Processing and preserving of fruit and vegetables & 282 Manufacture of tanks, central heating radiators and boilers \\
\hline 154 Manufacture of vegetable and animal oils and fats & 283 Manufacture of steam generators \\
\hline 155 Manufacture of dairy products & 284 Forging, pressing, stamping and roll forming of metal \\
\hline 156 Manufacture of grain mill products, starches and starch products & 2851 Treatment and coating of metals \\
\hline 157 Manufacture of prepared animal feeds & 2852 General mechanical engineering \\
\hline 1581-2 Manufacture of bread, biscuits and bakery products & 286 Manufacture of cutlery, tools and general hardware \\
\hline 1583-4 Manufacture of sugar, cocoa and chocolate & 287 Manufacture of other fabricated metal products \\
\hline 1585-9 Manufacture of other food products & \begin{tabular}{|c|} 
Manufacture of machinery and equipment \\
\end{tabular} \\
\hline 1591-7 Manufacture of alcoholic beverages & 291 Manufacture of machinery for the production of mechanical power \\
\hline 1598 Production of mineral waters and soft drinks & 292 Manufacture of other general purpose machinery \\
\hline 160 Tobacco products & 293 Manufacture of agricultural and forestry machinery \\
\hline Manufacture of textiles, wearing apparel, leather and footwear & 294 Manufacture of machine-tools \\
\hline 171 Preparation and spinning of textile & 295-6 Manufacture of other special purpose machinery and weapons \\
\hline 172 Textile weaving & 297 Manufacture of domestic appliances n.e.c. \\
\hline 173 Finishing of textiles & Manufacture of office machinery, computers and precision equipment \\
\hline 174 Manufacture of made-up textile articles, except a & 300 Manufacture of office machinery and computers \\
\hline 175 Manufacture of other textiles & 331 Manufacture of medical and surgic \\
\hline 176 Manufacture of knitted and crocheted fabrics & 332-5 Manufacture of instruments for measuring and \\
\hline 177 Manufacture of knitted and crocheted articles & Manufacture of electrical equipment \\
\hline 181-2 Manufacture of leather clothes and other wearing apparel & 311 Manufacture of electric motors, generators anc \\
\hline 183 Dressing and dyeing of fur; manufacture of articles of fur & 312 Manufacture of electricity distribution and control apparatus \\
\hline 191 Tanning and dressing of leather & 313 Manufacture of insulated wire and cable \\
\hline 192 Manufacture of luggage, handbags and the like, saddler & 315 Manufacture of lighting equipment and electric lamps \\
\hline 193 Manufacture of footwear & 314/316 Manufacture of accumulators and electrical equipr \\
\hline Manufactures of paper, paper products, publishing and printing & 321 Manufacture of electronic valves and other electronic components \\
\hline 211 Manufacture of pulp, paper and paperboard & 322 Manufacture of television, radio transmitters, apparatus for line telephony \\
\hline 212 Manufacture of articles of paper and paperboard & 323 Manufacture of television and radio receivers, sound or video recording \\
\hline 221 Publishing & Manufacture of transport equipment \\
\hline 222-3 Printing and service activities related to printing & 341 Manufacture of motor vehicles \\
\hline Manufacture of chemical & 342 Manufacture of bodies for motor vehicles, trailers and semi-trailers \\
\hline 241 Manufacture of basic chemicals & 343 Manufacture of parts, accessories for motor vehicles \\
\hline 242 Manufacture of pesticides and other agro-chemical products & 351 Building and repairing of ships and boats \\
\hline 243 Manufacture of paints, varnishes and similar coatings & 352 Manufacture of railway, tramway locomotives, rolling stock \\
\hline 244 Manufacture of pharmaceuticals, medicinal and botanical & 353 Manufacture of aircraft and spacecraft \\
\hline 245 Manufacture of soap, detergents, cleaning, polishing & 354-5 Manufacture of motorcycles and other transport equipment n.e.c. \\
\hline 246 Manufacture of other chemical products & Manufacture of wood, furniture; manufacturing n.e.c. \\
\hline 247 Manufacture of man-made fibres & 201 Sawmilling and planning of wood, impregnation of wood \\
\hline Manufacture of rubber and plast & 202 Manufacture of veneer sheets and other panels and boards \\
\hline 251 Manufacture of rubber products & 203 Manufacture of builders' carpentry and joinery \\
\hline 252 Manufacture of plastic products & 204 Manufacture of wooden containers \\
\hline Manufacture of other non-metallic mineral products & 2051 Manufacture of other products of wood \\
\hline 261 Manufacture of glass and glass products & 2052 Manufacture of articles of cork, straw and plaiting materials \\
\hline 262 Manufacture of ceramic goods & 361 Manufacture of furniture \\
\hline 263-4 Manufacture of construction products & 362 Manufacture of jewellery and related articles \\
\hline 265 Manufacture of cement, lime and plaster & 364-5 Manufacture of sports goods and games and toys \\
\hline 266 Manufacture of articles of concrete, plaster & 363/366 Miscellaneous manufacturing n.e.c. \\
\hline
\end{tabular}

267 Cutting, shaping and finishing of stone

268 Manufacture of other non-metallic mineral products

Manufacture of basic metals

271 Manufacture of basic iron and steel and of ferro-alloys (ECSC)

272 Manufacture of tubes

273 Other first processing of iron and steel

274 Manufacture of basic precious and non-ferrous metals

275 Casting of metals 
Table 2: Outsourcing explanatory variables and expected signs in previous literature

\begin{tabular}{|c|c|c|}
\hline Variable & Expected sign & Previous works \\
\hline Labour costs & + & $\begin{array}{c}\text { Abraham and Taylor (1996) } \\
\text { Girma and Görg (2004) } \\
\text { Görg and Hanley (2004) } \\
\text { Holl (2004) }\end{array}$ \\
\hline \multirow{2}{*}{ Firm Size } & - & Abraham and Taylor (1996) \\
\cline { 2 - 3 } Market Size \\
[Export propensity] & + & $\begin{array}{c}\text { Tomiura (2005) } \\
\text { Holl (2004) }\end{array}$ \\
\hline \multirow{2}{*}{\begin{tabular}{c} 
National ownership \\
\cline { 2 - 3 }
\end{tabular}} & - & $\begin{array}{c}\text { McLaren (2000) } \\
\text { [Görg and Hanley (2004)] }\end{array}$ \\
\cline { 2 - 3 } Previous outsourcing \\
level
\end{tabular}

Table 3: Summary Statistics

\begin{tabular}{|l|cc|cc|cc|}
\cline { 2 - 7 } \multicolumn{1}{c|}{} & \multicolumn{2}{c|}{1993} & \multicolumn{2}{c|}{2002} & \multicolumn{2}{c|}{ 1993-2002 } \\
\cline { 2 - 7 } \multicolumn{1}{c|}{} & Mean & Std. Deviation & Mean & Std. Deviation & Mean & Std. Deviation \\
\hline Outsourcing & 3.83 & 3.59 & 5.11 & 4.71 & 4.49 & 4.17 \\
Unit Labour Cost & 24.27 & 7.68 & 18.26 & 5.98 & 19.55 & 6.78 \\
\% Small Firms & 79.21 & 12.18 & 74.91 & 13.21 & 77.55 & 13.20 \\
Export Propensity & 28.01 & 20.07 & 31.16 & 19.46 & 29.76 & 19.28 \\
National Ownership & 77.53 & 12.14 & 77.41 & 13.10 & 77.14 & 12.37 \\
Foreign market penetration & 5.15 & 3.59 & 8.02 & 4.98 & 6.78 & 4.64 \\
Skills (dummy) & 0.12 & 0.33 & 0.12 & 0.33 & 0.09 & 0.28 \\
\hline
\end{tabular}
Source: Industrial Companies Survey, Comext, Survey of Firm Strategies and Peneder (1999).

Note: All the variables are before taking logarithms.

Table 4: Simple Correlations between variables

\begin{tabular}{|l|c|c|c|c|c|c|c|}
\cline { 2 - 8 } \multicolumn{1}{c|}{} & Outsourcing & ULC & $\begin{array}{c}\% \text { Small } \\
\text { firms }\end{array}$ & $\begin{array}{c}\text { Export } \\
\text { Propensity }\end{array}$ & $\begin{array}{c}\text { National } \\
\text { Ownership }\end{array}$ & $\begin{array}{c}\text { Foreign-market } \\
\text { penetration }\end{array}$ & Skills \\
\hline Outsourcing & 1.000 & & & & & & \\
\hline Unit Labor Cost & 0.440 & 1.000 & & & & & \\
\hline$\%$ Small Firms & 0.155 & 0.176 & 1.000 & & & & \\
\hline Export Prop. & 0.184 & 0.153 & -0.320 & 1.000 & & & \\
\hline National Own. & 0.385 & 0.159 & 0.421 & -0.183 & 1.000 & & 1.000 \\
\hline Foreign-market penet. & 0.184 & 0.042 & -0.293 & 0.411 & -0.126 & 0.298 & 1.000 \\
\hline Skills & 0.321 & 0.281 & -0.080 & 0.249 & -0.109 & 09 \\
\hline
\end{tabular}


Table 5: Determinants of Outsourcing (GMM Regression Results).

\begin{tabular}{|c|c|c|c|c|c|}
\hline Parameters & (1) & (2) & (3) & (4) & (5) \\
\hline Outsourcing $_{t-1}$ & $\begin{array}{c}0.802^{* \star *} \\
(0.029)\end{array}$ & $\begin{array}{c}0.789^{\star \star *} \\
(0.031)\end{array}$ & $\begin{array}{c}0.802^{\star * \star} \\
(0.029)\end{array}$ & $\begin{array}{c}0.827^{\star * *} \\
(0.031)\end{array}$ & $\begin{array}{c}0.922^{\star \star \star} \\
(0.018)\end{array}$ \\
\hline ULC & $\begin{array}{c}0.288^{* \star *} \\
(0.097)\end{array}$ & $\begin{array}{l}0.282^{\star \star} \\
(0.128)\end{array}$ & $\begin{array}{l}0.255^{\star *} \\
(0.126)\end{array}$ & $\begin{array}{l}0.159^{* *} \\
(0.072)\end{array}$ & $\begin{array}{l}0.107^{\star *} \\
(0.048)\end{array}$ \\
\hline$\%$ Small-firms & $\begin{array}{l}-0.031 \\
(0.101)\end{array}$ & $\begin{array}{c}-0.277^{*} \\
(0.151)\end{array}$ & & $\begin{array}{l}-0.233^{*} \\
(0.132)\end{array}$ & $\begin{array}{l}-0.055 \\
(0.047)\end{array}$ \\
\hline National-ownership & $\begin{array}{l}0.342^{\star *} \\
(0.136)\end{array}$ & $\begin{array}{c}0.533^{\star \star \star} \\
(0.169)\end{array}$ & $\begin{array}{c}0.365^{\star \star \star} \\
(0.135)\end{array}$ & $\begin{array}{c}0.443^{* * *} \\
(0.135)\end{array}$ & $\begin{array}{c}0.308 \\
(0.209)\end{array}$ \\
\hline Export-propensity & $\begin{array}{l}-0.005 \\
(0.028)\end{array}$ & & $\begin{array}{l}-0.015 \\
(0.033)\end{array}$ & & $\begin{array}{l}0.013^{*} \\
(0.006)\end{array}$ \\
\hline Foreign-market penetration & & & & $\begin{array}{l}0.010^{*} \\
(0.006)\end{array}$ & \\
\hline Standardization & $\begin{array}{l}-0.084^{*} \\
(0.050)\end{array}$ & $\begin{array}{l}-0.097^{*} \\
(0.057)\end{array}$ & $\begin{array}{l}-0.114^{*} \\
(0.061)\end{array}$ & $\begin{array}{l}-0.067 \\
(0.052)\end{array}$ & \\
\hline High Skills & $\begin{array}{l}0.033^{*} \\
(0.017)\end{array}$ & $\begin{array}{c}0.040 \\
(0.026)\end{array}$ & $\begin{array}{l}0.040^{* *} \\
(0.018)\end{array}$ & $\begin{array}{l}0.037^{*} \\
(0.018)\end{array}$ & \\
\hline Constant & $\begin{array}{c}-0.674^{\star *} \\
(0.268) \\
\end{array}$ & $\begin{array}{l}-0.595^{\star} \\
(0.317) \\
\end{array}$ & $\begin{array}{c}-0.196 \\
(0.359) \\
\end{array}$ & $\begin{array}{l}-0.424 \\
(0.257) \\
\end{array}$ & $\begin{array}{c}-0.062 \\
(0.145) \\
\end{array}$ \\
\hline Observations & 783 & 828 & 783 & 828 & 207 \\
\hline Sectors & 87 & 92 & 87 & 92 & 23 \\
\hline Test (p-values) & & & & & \\
\hline $\operatorname{AR}(1)$ & 0.000 & 0.000 & 0.000 & 0.000 & 0.000 \\
\hline $\operatorname{AR}(2)$ & 0.318 & 0.337 & 0.329 & 0.381 & 0.189 \\
\hline Sargan test & 1.000 & 0.993 & 0.994 & 1.000 & 1.000 \\
\hline
\end{tabular}

Notes: Standard errors in parenthesis; statistically significant ${ }^{*}$ at $10 \%,{ }^{* *}$ at $5^{*},{ }^{* * *}$ at $1 \%$.

All equations include year dummies. $A R(1)$ and $A R(2)$ are tests of first and second order serial correlation. Sargan is a test of the over-identifiying restrictions (twostep estimations). P-values below 0.05 suggest a rejection of the validity of the instruments at the $5 \%$ critical level. 


\section{Figure 1: Dimensions of Fragmentation of Production.}

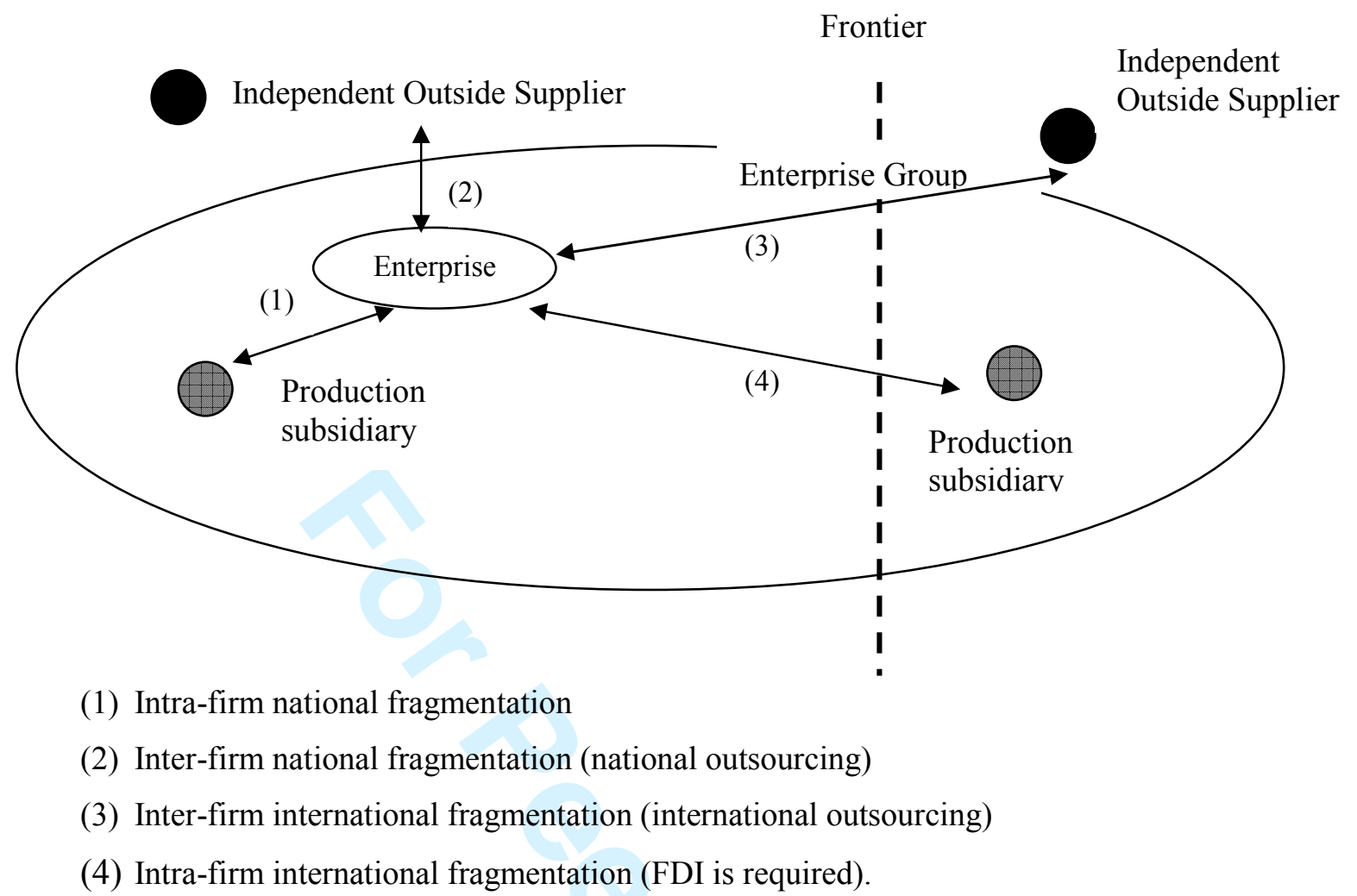

Source: Own elaboration from Kimura and Ando (2005) and Curzon Price (2001). 
Figure 2: Outsourcing of Internal Production: Level in 2002 and Change 1993-2002

(Production works carried out by other companies / Gross production, in percentage; change in percentage points)

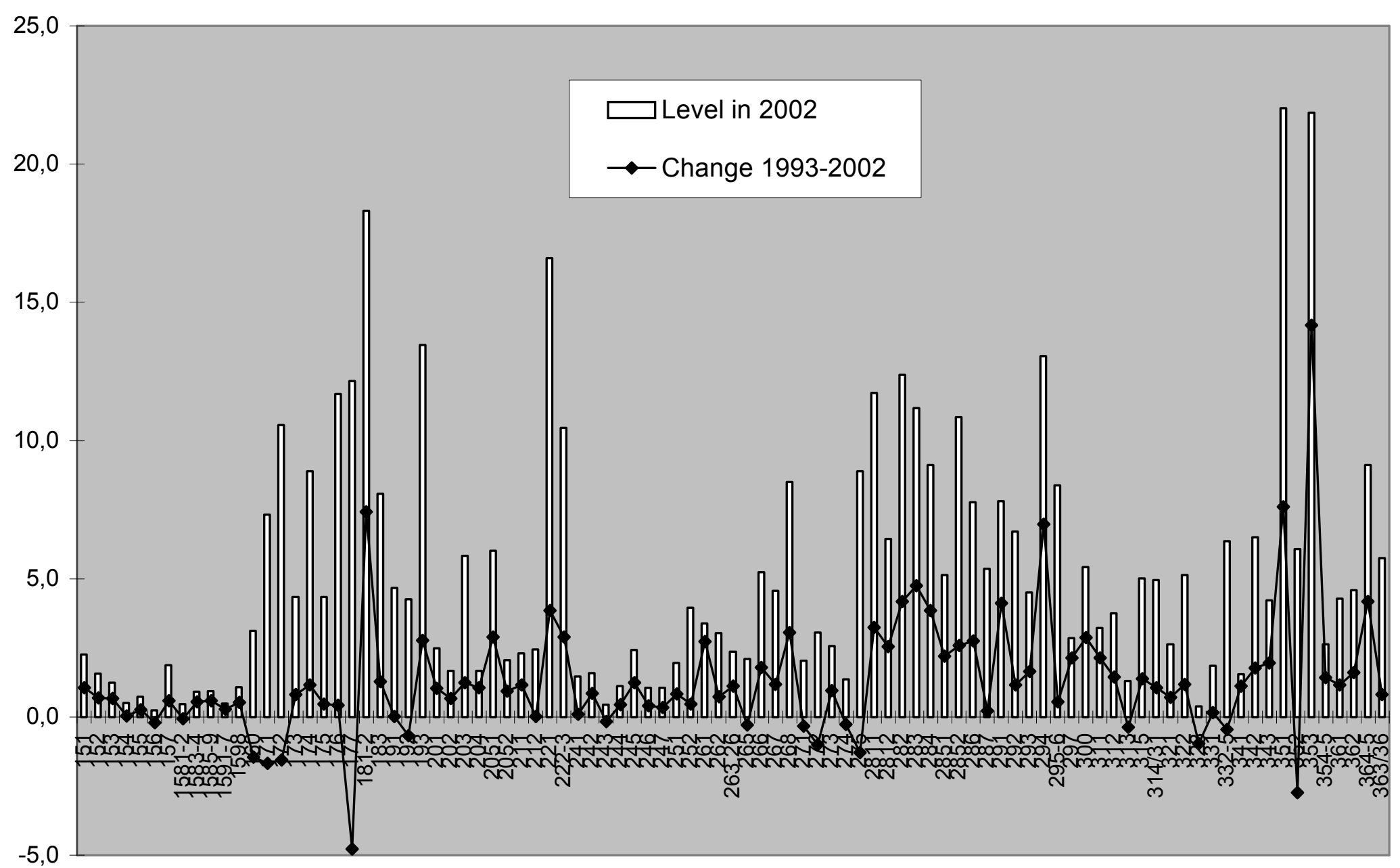

Source: Industrial Companies Survey 2002 (National Statistical Institute of Spain). 
Figure 3: Outsourcing of production according to industry taxonomy based on factor inputs

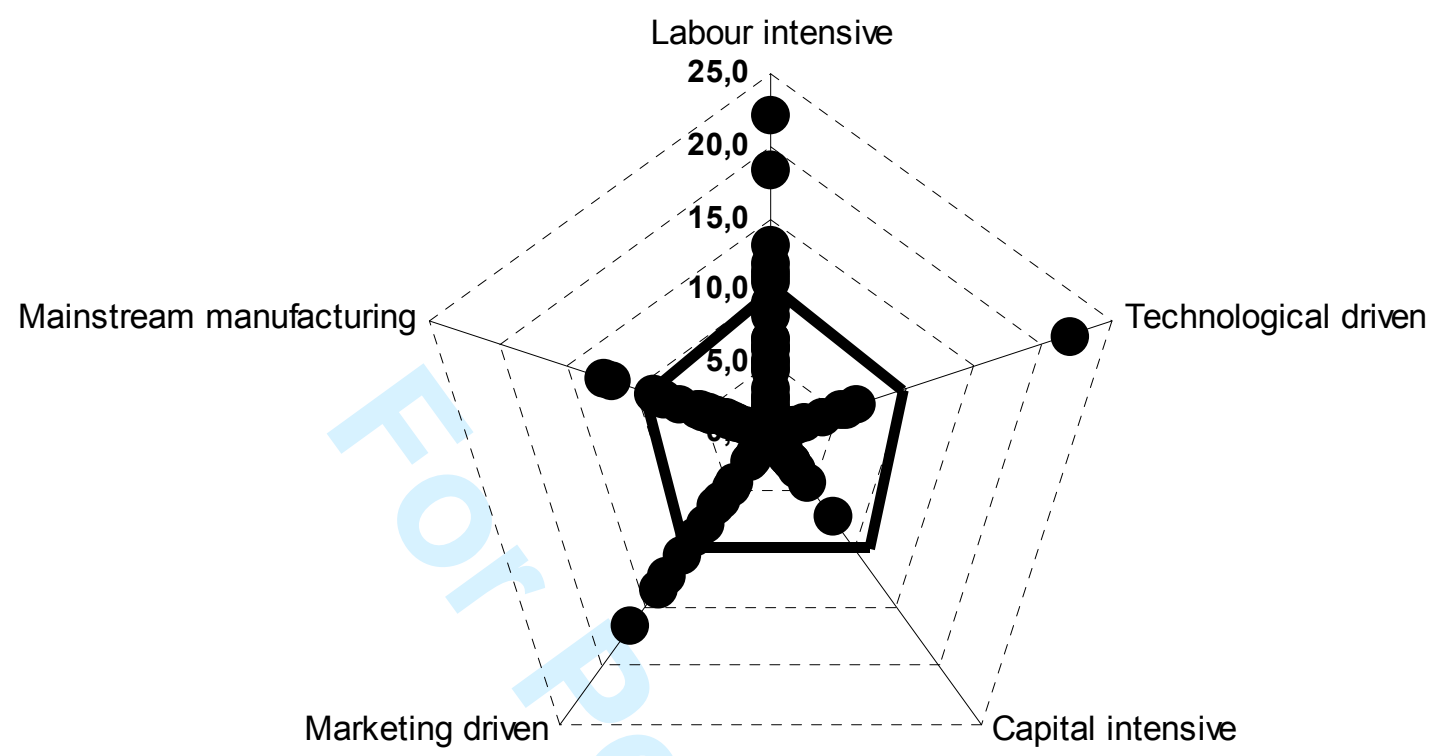

Source: Industrial Companies Survey 2002 (National Statistical Institute of Spain) and Peneder (1999). 


\begin{abstract}
* I am indebted to Rosario Gandoy, Juan Ignacio Palacio and Oscar Bajo for constructive comments on a previous version of this paper. I also thank participants at the $7^{\text {th }}$ European Trade Study Group Conference (Dublin, Ireland, September 2005) as well as an anonymous referee for helpful suggestions. Financial support by the Consejería de Educación y Ciencia of the Junta de Comunidades de Castilla-La Mancha under the project PBI-05-021, cofinanced by FEDER funds, is gratefully acknowledged.
\end{abstract}

${ }^{\text {i }}$ See Piore and Saber (1984). The higher flexibility can be obtained through flexible production which allows firms to adapt standardized inputs to a variety of specifications (Eckel, 2004). Through flexible production, firms can alter the final goods they provide according to the specific needs or desires of their customers.

${ }^{\text {ii }}$ Nevertheless, fragmentation of production and outsourcing are often treated as synonymous. The term outsourcing comes from the compound expression "outside resource using". Along this paper, the terms outside and external refer to outside or external to the firm.

iii The Economist has recently published a survey of outsourcing, in which is pointed that "manufacturing has already gone a long way down the road of outsourcing" (The Economist, November 13 ${ }^{\text {th }}$ 2004).

${ }^{\text {iv }}$ Tomiura (2005) employs a similar indicator but, as pointed out above, he uses cross-section data. Holl (2004) opt for a narrower indicator, the subcontracting of products, parts and components, to study the probability of outsourcing. At last, Girma and Görg (2004) use a bit wider measure, the industrial services receive, which comprises activities such as processing of inputs but also certain services as maintenance of production machinery or engineering services.

${ }^{v}$ Various types of outsourcing exist in the manufacturing industries depending on the relationship between the principal and the third-party company. Subcontracting is a particular case where a "dominant/dominated" relationship is created. Specifically, subcontracts correspond to the relationship between two companies (the subcontractor and the main contractor), where the subcontractor company participates in the production process of a particular product, which belongs to the contractor company. The subcontract conditions require the main contractor to provide a diagram and precise technical specifications for the manufacture of the product, as well as the supply of its main raw materials.

${ }^{\mathrm{vi}}$ In the context of transaction costs and contractual incompleteness Grossman and Helpman (2002) examine theoretically the decision between outsourcing or vertical integration of intermediate inputs (make or buy decision) taking into account the costs that arise from search frictions and imperfect contracting and the costs of running a larger and less specialized organization. To consider the international dimension as well as the ownership dimension, Antras and Helpman (2004) develop a theoretical framework in which, based on productivity and sectoral characteristics, firms decide whether to integrate into the production of intermediate inputs or outsource them and firms also choose the location of inputs production (at home or abroad).

${ }^{v i i}$ A strategic motive can be added to these usual motives for outsourcing when a firm outsourcing decision affects the rivals' outsourcing decisions and the firm takes into account it in the decision process. Shy and Stenbacka (2003) and Buehler and Haucap (2006) study how firms may strategically outsource the productions of inputs analysing the trade-off between the fixed cost of investing into in-house production facilities for an input or the higher marginal cost for sourcing the input over the market (which is caused by changes in input demand and inputs prices).

viii This hypothesis is in accordance to Antras (2003) who using a model of outsourcing based on the property rights approach shows that final goods in the capital-intensive sector are produced under vertical integration whereas those in the labour-intensive sector are outsourced.

${ }^{\text {ix }}$ This increase is higher than the average scored by German manufacturing enterprises, which has placed in $27 \%$ for the period 1992-2000 according to Görzig and Stephan (2002). However, it should be noted that the fragmentation processes in German industry had most probably taken place before the 1990s.

${ }^{\mathrm{x}}$ The sector "Manufacture of office machiney and computers" has been removed from the econometric analysis. The data in 2002 show a sharp decrease of output which is not present in employment or number of enterprises suggesting a measure error for that year. Since the indicador of outsourcing used is calculated related to output, the level of fragmentation will be overestimated.

${ }^{\mathrm{xi}}$ Although some American and British firms have already begun to outsource some of their business services abroad (so far mostly to India), the outsourcing of white-collar work is still only emerging (The Economist, November $13^{\text {th }}$ 2004).

${ }^{x i i}$ Following Piga and Vivarelli (2003) those firms which face tougher foreign competition may exhibit a stronger tendency to cooperate. For this reason, we also could expect that firms competing in international markets were more prone to engage in outsourcing agreements.

xiii The author is grateful to the anonymous referee for this suggestion. 